\title{
ATOMIC FORCE MICROSCOPY APPLIED TO ATOPIC DERMATITIS STUDY
}

\author{
Simona Maria Jîrcă $\breve{1}^{1,2}$, Ion Jîrcă $\breve{3}^{3}$, Marius Sorin Ciontea ${ }^{4}$, Florin Dumitru Mihălţan ${ }^{5}$ \\ ${ }^{1}$ County Hospital, Târgu Jiu, Romania \\ "2 Carol Davila" University of Medicine and Pharmacy, Bucharest \\ ${ }^{3}$ Faculty of Sciences, University of Craiova, 200585 Craiova \\ 4"Tudor Vladimirescu" Hospital of Pneumology, Runcu, Gorj \\ "Marius Nasta" Institute of Pneumophtisiology, Bucharest \\ Correspondence to: Simona Maria Jîrcă, simonanistorescu@gmail.com
}

\section{Rezumat}

Dermatita atopică (DA) este cea mai frecventă boală inflamatorie a pielii, care afectează până la 25\% dintre copii și 2\% până la 5\% dintre adulți. Metodele de diagnostic oferă recomandări extinse bazate pe dovezile disponibile. Evaluarea morfologică rămâne o caracteristică principală a investigației clinice și principalul criteriu de diagnostic.

Metodă. Am colectat pielea normală și afectată de la un pacient cu vârsta de 6 luni care a fost diagnosticat prin examen dermatologic. Caracteristicile clinice și diagnosticul de dermatită atopică au fost în conformitate cu criteriile Hanifin și Rajka. Morfologia și integritatea structurală au fost investigate prin microscopie de forță atomică.

Rezultate. Imaginile optice și topografice indică faptul că, în cazul DA leziunilor cutanate, structura cuticulei a fost grav deteriorată și distorsionată odată cu aplatizarea și încrețirea plăcilor, care au un aspect neregulat. Din morfologiile de suprafață ale probelor, demonstrăm că forma corneocitelor, cu aspect granular și alungit, specifică pielii normale este transformată în plăci rupte și deteriorate cu aspect discontinuu in DA.

Concluzii:. În diagnosticul inițial al DA, modificările proprietăților pielii pot fi un indicator. Criteriile Hanifin și Rajka împreună cu microscopia de forța atomica pot fi o tehnică utilă și necesară diagnosticării cazurilor de dermatită atopică.

Cuvinte cheie: dermatită atopică, microscopie de forță atomică.

\begin{abstract}
Atopic dermatitis (AD)-the commonest inflammatory skin disease affects up to $25 \%$ of children and $2 \%$ to $5 \%$ of adults. Methods of the diagnostic provide expanded recommendations founded on available evidence. Morphological evaluation remains a principal feature of clinical investigation and the main criteria of diagnosis.
\end{abstract}

Methods. We collected normal and affected skin from a 6-month child patient who was diagnosed through dermatologic examination. Clinical characteristics and the diagnosis of 


\section{INTERNAL MEDICINE} Original Papers

atopic dermatitis were in accordance with Hanifin and Rajka criteria. Morphology and structural integrity were investigated by Atomic Force Microscopy.

Results. Optical and topography images indicate that in the case of AD skin lesions the cuticle structure was severely damaged and distorted with the flattening and grading of the plates, which have an irregular appearance. From the surface morphologies of the samples, we demonstrate that the shape of the corneocytes, with granular and elongated appearance, specific to normal skin is transformed by $A D$ into broken and collapsed plates with discontinuous appearance.

Conclusions. In the initial diagnosis of $A D$ changes of the skin properties can be an indicator. Hanifin and Rajka criteria together with Atomic Force Microscopy can be a useful and necessary technique diagnosing cases of atopic dermatitis.

Keywords: atopic dermatitis, atomic force microscopy.

\section{Introduction}

Atopic dermatitis (AD) is a chronic inflammatory or recurrent skin disease, and plays an important role in the quality of life among affected persons and their families becoming a major issue in health care spending $^{(1,2,3)}$.

Recent studies indicate an increase in the prevalence of $A D$ and allergic diseases in industrialized countries ${ }^{(4)}$. Prevalence ranges from $2.1 \% / 1.5 \%$ in Japan to $4.9 \%$ / 3.9\% in the US and $3.5 \%$ in Europe ${ }^{(1,5)}$. A percent of $10-15 \%$ in the case of children with age before school age is usually meet. Children with $A D$ are at high risk of developing asthma and allergic rhinitis. Of those with $A D$ before
2 years of age, $50 \%$ will develop asthma later $^{(2,6,7)}$.

$A D$ is one of the first indicators for subsequent allergic diseases; imposing the idea, that quality control of $A D$ may prevent the development of respiratory allergy or reduce the severity of asthma. Numerous studies have shown that $A D$ and asthma have a common genetic and pathogenic basis, providing evidence for the atopic walk from $A D$ to allergic rhinitis and asthma ${ }^{(4)}$.

Clinical features of atopic dermatitiseczematous lesions, intensely itchy, which become excoriated and lichenified, vary depending on the stage (acute or chronic) of the disease and the age of the patients ${ }^{(2,8)}$. Infants may have gray plaques or white scabs 
on the scalp, associated with damage to the face, neck, trunk, ankles and extension and flexural areas of the extremities ${ }^{(9)}$.

Patient history and clinical manifestations are the main clinical criteria for the diagnosis of $A D$, while specific paraclinical diagnostic tests do not exist ${ }^{(2,10)}$.

Skin changes in $A D$ are complex processes that involve a modification in cell structure, chemistry, and function ${ }^{(11,12)}$.

Atomic Force Microscopy is a new technique commonly used in surface imaging. Length and height measurements are performed to generate topographic images at the nanometric and micrometric scale, due to its very high resolution which is more than 1,000 times better than optical microscopy, with several orders of magnitude above the normal detection of optical microscopes. An Atomic Force Microscopy is based on the interaction forces between a sharp tip attached to the extremity of a flexible cantilever and the sample surface that determines the cantilever's deflection.

The small deviations of the cantilever are detected by an optical lever system exploiting the reflection of a fixed laser beam over a small mirror attached to the body and the position of the point of light is also measured are used as a basis to reconstruct a pseudo-3D image of the sample surface ${ }^{(13,14)}$.

Atomic force microscopy was used to analyze the individual corneocytes that are the outermost layer of the epidermis. Kashibuchi et al. performed the detailed study on 3D morphology of corneocytes isolated from the upper arm and cheek of volunteers of different ages ${ }^{(15)}$.

The main objective of our work was to investigate the microstructures and the properties at the nanometric scale of skin affected by atopic dermatitis. Using AFM we verify and confirm this hypothesis and correlated with the Hanifin and Rajka criteria which are the basis for the diagnosis of $A D$. The diagnosis of AD was made clinically and is based on historical features, morphology and distribution of skin lesions, and associated clinical signs. In this study, the patient presents 3 major Hanifin and Rajka criteria including pruritus, typical morphology and distribution, facial and extensor eruptions, and personal or family history of atopy (asthma, allergic rhinitis, atopic dermatitis). Other minor criteria which include early age of onset, anterior neck folds, perifollicular accentuation, and a tendency toward nonspecific hand or foot dermatitis.

Clinical characteristics ${ }^{(16,17,18,19,20)}$ and the diagnosis of atopic dermatitis were in accordance with Hanifin and Rajka criteria.

\section{Materials and Methods}

We present the case of a 6 month-old male infant who was evaluated in Allergy Department for skin lesions who is characterized by a lively red infiltrate, crusting, excoriations and squamous erythematous plaques ; eczema is localized at the flexures of the elbows and legs and to the face.
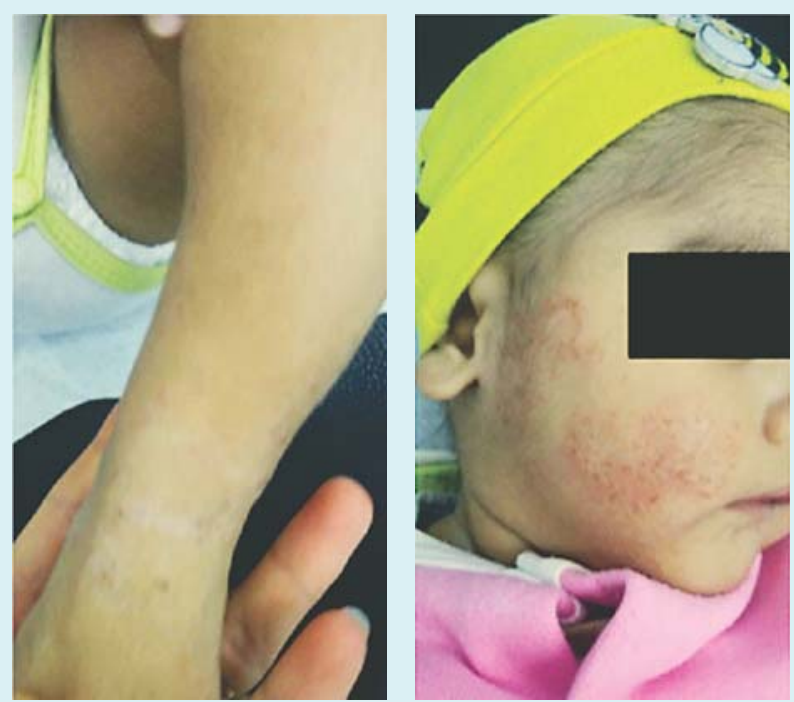

Figure 1. (a) Clinical images of a 6-month-old female of the forearm; (b) face 


\section{Original Papers}

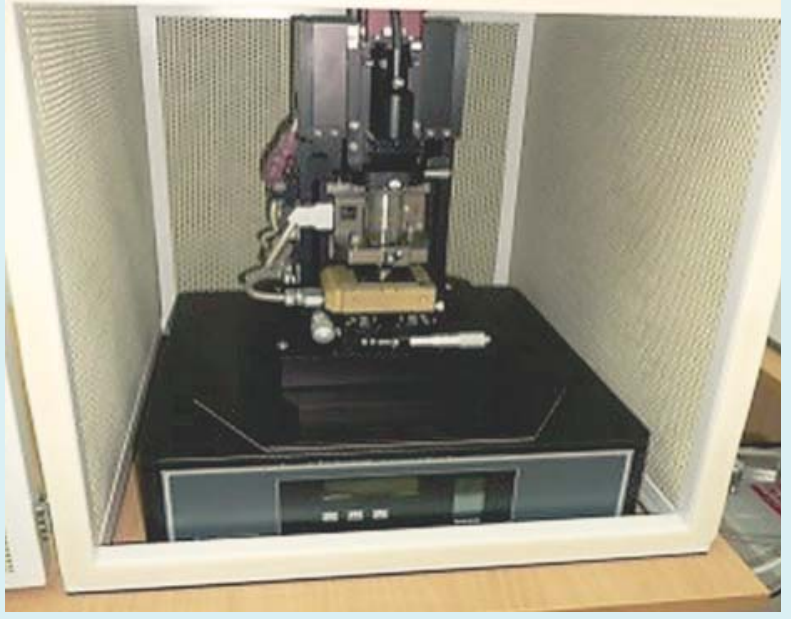

Figure 2. Atomic Force Microscopy, Park XE-100 equipment

Squamous erythematous plaques were removed from the patient skin with lesion (Figure 1 - $a$ and b). The samples were taken directly from the cheek by scraped, afterward the skin morphology was evaluated using AFM. Normal skin samples were taken and examined in the same way and used for comparison. All skin samples were fixed in same mode on a glass slide and the probe was measured directly without extra treatment.

To investigate the surface topography the skin samples were collected with a scalpel blade and are superficial. Initially, the microscope slides were cleaned and left in the ultrasonic bath with ethanol to avoid contamination. Tissue samples were transferred onto a glass slide immediately after collection to prevent tissue autolysis and decomposition. Small wax bites melted, which is very close to the room temperature, has been dripped onto the surface of the blades so that the corners of the skin sample are glued to the blade. Gluing at the center of the sample was avoided to eliminate the risks of deforming the samples ${ }^{(11)}$.

In this study, for samples were removed only the outermost layers of skin with a special razor blade or scalpel. It was only necessary to use the tools to detach the outer portion of the affected skin and to place it on the glass slide so that the integrity of the surface was as little affected as possible, not for deep cutting.

No antiseptic, preoperative or hygiene treatments were applied on the specimens, in case of their use there is a risk of alteration or hydration of the samples, which would have led to false images and affected morphological characteristics. In order to obtain the necessary skin samples in this study, a biopsy was not required, as in the case of cancer therapies, this obtaining procedure described in the article produces a minimum of both mental and cosmetic discomfort and does not require the use of local anesthesia.

In addition, Atomic Force Microscopy does not require thick pieces of skin, (specimens a few microns thick can be scanned) and therefore only skin surface specimens were involved in 

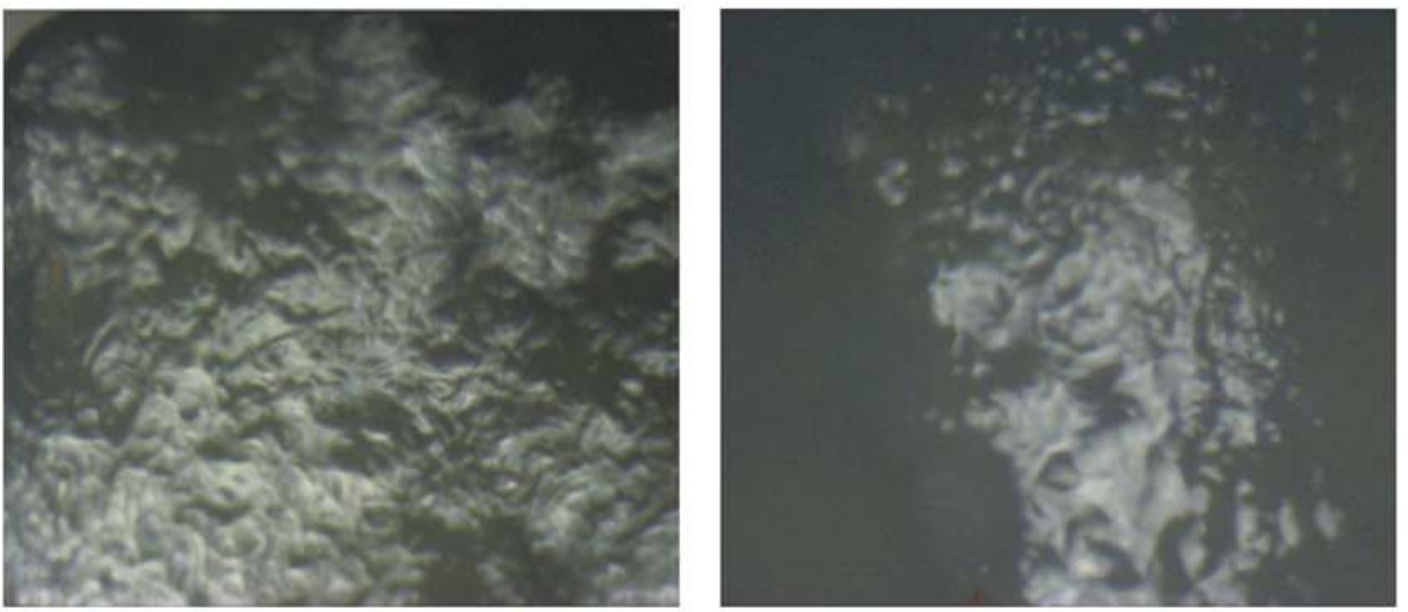

Figure 3. (a) Optical images of control skin; (b) AD skin, scanned area $40 \times 40 \mu \mathrm{m}^{2}$
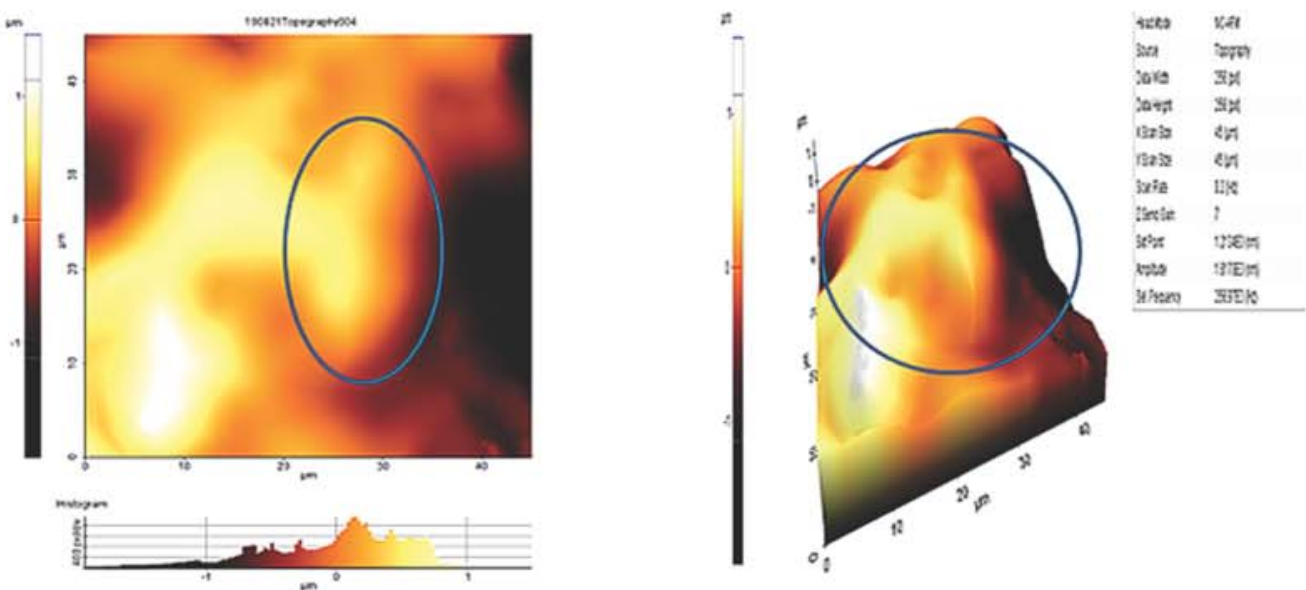

Figure 4. (a) 2D surface topography for the control skin; (b) 3D surface topography for the control skin, scanned area, $40 \times 40 \mathrm{\mu m}^{2}$. The blue circle indicates form of corneocyte. Height is given in colour brightness - lateral dimension by scale bar $(1 \mu \mathrm{m})$. The graphs under figures indicate a cross-section that of samples
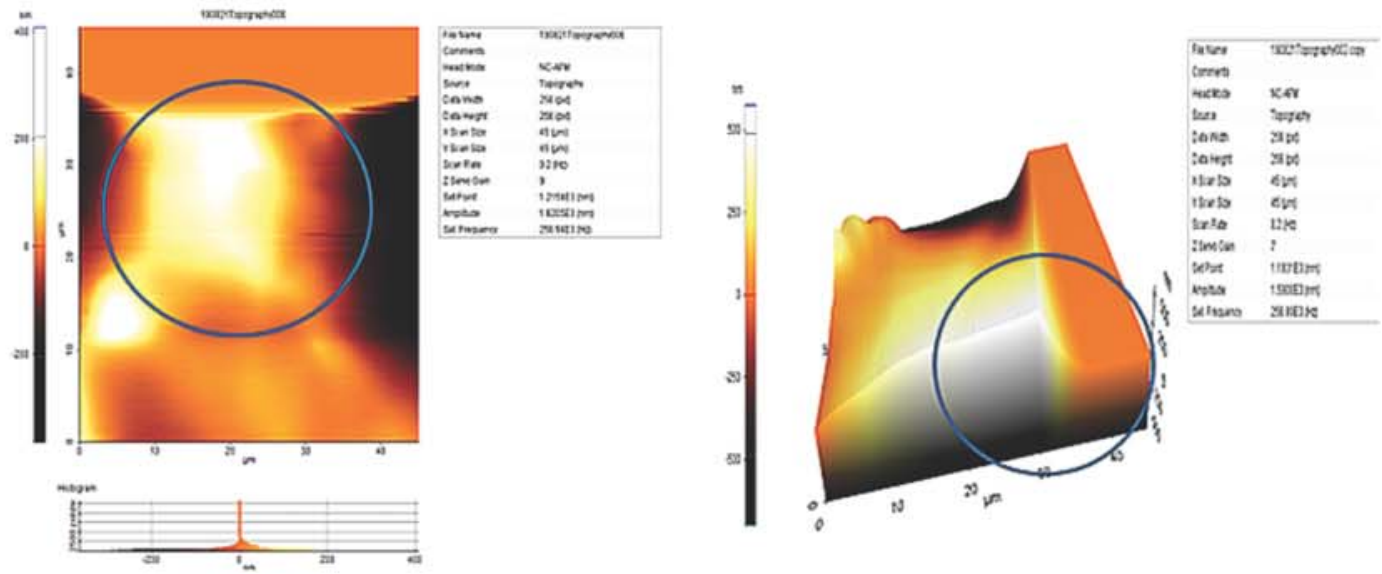

Figure 5. (a) $2 D$ surface topography collected from lesion regions of $A D$; (b) $3 D$ surface topography collected from lesion regions of $A D$, scanned area, $40 \times 40 \mu \mathrm{m} 2$. The blue circle indicates form of corneocyte. Height is given in colour brightness - lateral dimension by scale bar $(1 \mu \mathrm{m})$. The graphs under figures indicate a crosssection that of samples. Height fluctuations in the graph indicate increased cell surface roughness 
the study. The scanning area is $40 * 40$ microns so it is not important that the edges of the sample are well delimited. Before capturing the topography images, some photos were scanned and evaluated. The scanned area was initially evaluated in terms of microscopic characteristics and the edges are generally avoided in these evaluations because it is tried to avoid breaking the cantilever of the Atomic Force Microscope.

The surface topographies were recorded using AFM, Park XE-100 equipment (silicon tip with conical shape) in the standard imaging Non-contact atomic force microscopy, with cantilever nominal length of $125 \mathrm{~mm}$, nominal force constant of $40 \mathrm{~N} / \mathrm{m}$, oscillation frequencies in the range of $275-373 \mathrm{kHz}$ (Figure 2). In the non-contact mode the cantilever is never in contact with the sample, and the forces between tip and the sample are attractive. The surface topographies were recorded five to seven times for each sample over a scan area of $40 * 40 \mu \mathrm{m}^{2}$. We used horizontal line by line flattening as planarization method.

\section{Results}

Morphological differences at nanometric scale between affected and healthy skin may be helpful in diagnosing AD.

In the present study, the morphology of the surface was investigated. Initially, optical images of the samples of the skin affected by $A D$ were scanned and recorded and compared with the control (healthy skin). (Figure 3) a and 3b show representative AFM optical images of $A D$ and control skins.

Figures $4 \mathrm{a}$ and $4 \mathrm{~b}$ show the $2 \mathrm{D}$ and $3 \mathrm{D}$ surface topography taken in an area of $40 * 40 \mu \mathrm{m}^{2}$ for the control skin and figure $5 \mathrm{a}$ and $5 \mathrm{~b}$ shows the surface topography collected from lesion regions of $A D$, respectively.

\section{Discussion}

A significant difference in the surface morphology was observed between the $A D$ skins and control skins. In AD skin lesions the cuticle structure was severely damaged and distorted.

The difference in topography of the cuticles between the $A D$ and control skin is more clearly seen in three-dimensional images of the surface and the line profiles, which were measured in the position as indicated with red and green lines in AFM images (Figure 6 $a$ and $b$ ).

The surface architecture, the shape of the corneocytes, the granular and elongated appearance, is transformed into broken and collapsed plates with discontinuous appearance. In the case of $A D$ samples, the cuticles can be damaged and deformed, together with the flattening and grading of the plates, which have an irregular 

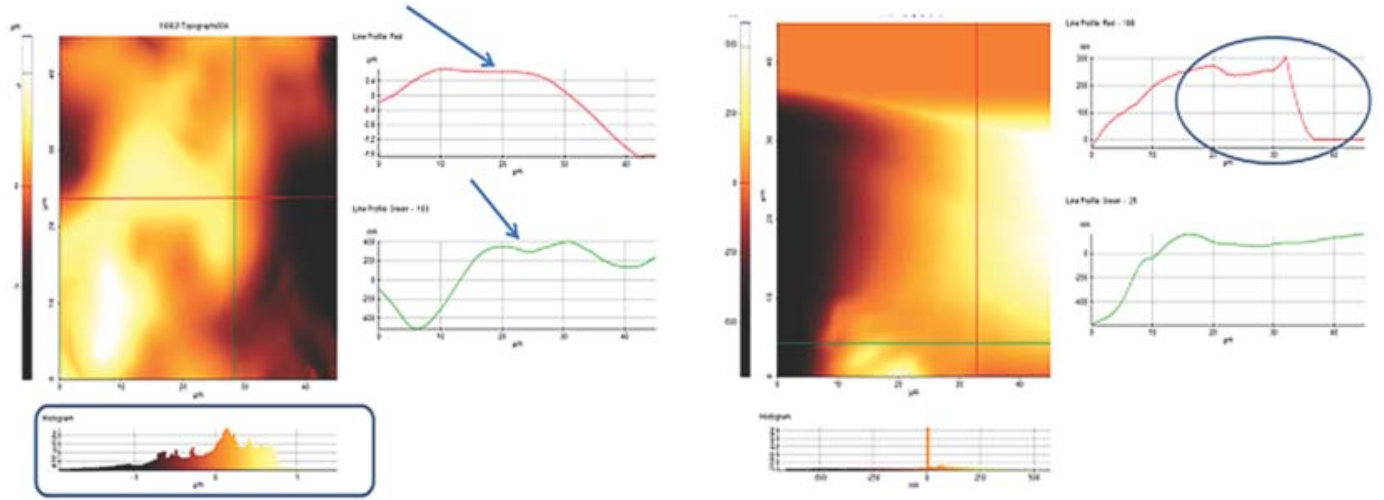

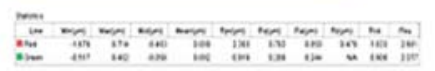

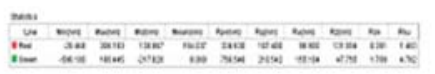

Figure 6. (a) Surface morphology and line profiles of the control skins; (b) Surface morphology and line profiles of the $A D$ skins. (a) Blue arrows indicate the profile of corneocyte; (b) The destruction of the corneocytes is confirmed by the steep profile in the blue circle. Height is given in colour brightness - lateral dimension by scale bar $(1 \mu \mathrm{m})$. Red lines represent horizontal line profiles and green lines represent vertical line profiles. The blue lines indicate a flat surface along two profile lines and in the blue circle in figure $b$ is presented the destruction of the shape of the corneocytes

appearance. These differences can be more easily observed with the help of the profile lines, where differences in both flatness and severe damage to the cuticle edge are observed (Figure 6 - $a$ and b).

\section{Conclusions}

The results proved that depending on the presence of $A D$, morphological parameters of corneocytes were different. The 3D characteristics of corneocytes in the diseased skin varied significantly from those of healthy skin. The volume of corneocytes was larger in the case of unhealthy skin. We observed $A D$ effects on cuticle structure and scale by AFM. The cuticle was damaged severely by $A D$; specifically, the edge of the cuticle was torn and collapsed.

In conclusion, we can say that the purpose of our work has been achieved. A case confirmed with the Hanifin and Rajkaa criteria was subjected to further investigations to confirm the hypotheses of nanometric destruction of the skin structure using the atomic force microscopy technique. Structural changes of the skin can be an indicator in the initial diagnosis of atopic dermatitis, and together with other criteria such as Hanifin and Rajka can form the complete picture of the diagnosis. Atomic force microscopy can be a useful and necessary technique in diagnosing cases of atopic dermatitis.

\section{Conflict of interest}

On behalf of all authors the corresponding author states that there is no conflict of interest.

\section{References}

1. Barbarot S, Auziere S, Gadkari A, Girolomoni G, Puig $L$, Simpson EL, Margolis DJ, de Bruin-Weller M, Eckert $L$. Epidemiology of atopic dermatitis in adults: Results from an international survey. Allergy 2018;73(6):1284-93, doi: 10.1111/all.13401.

2. Wade W, Sandeep K. Atopic dermatitis. Allergy, Asthma \& Clinical Immunology 2011;7 Suppl 1:S4, 
.

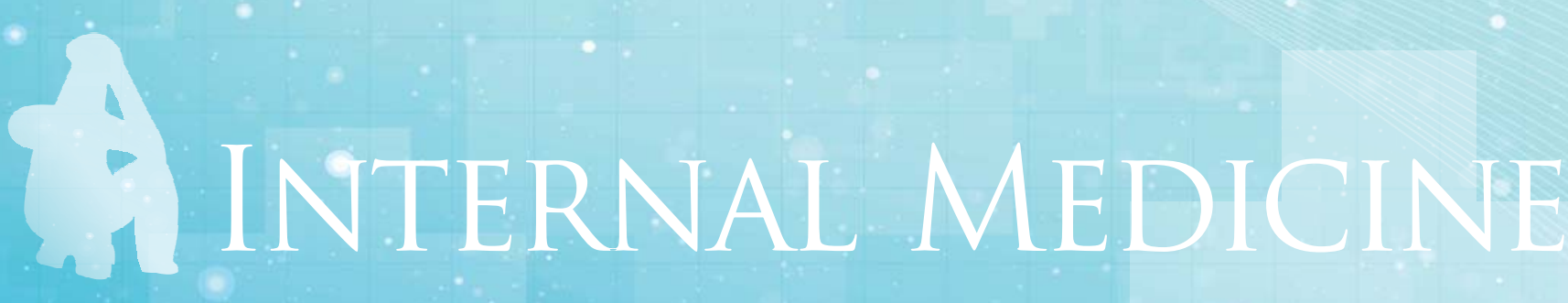

\section{Original Papers}

doi.org/10.1186/1710-1492-7-S1-S4

3. Bieber T. Atopic Dermatitis. Ann Dermatol 2010;22(2):125-37, doi: 10.5021/ad.2010.22.2.125.

4. Galli E, Gianni S, Auricchio G, Brunetti E, Mancino G, Rossi P. Atopic dermatitis and asthma. Allergy Asthma Proc 2007;28(5):540-3, DOI:10.2500/aap2007.28.3048.

5. Yew YW, Thyssen JP, Silverberg JI. A systematic review and meta-analysis of the regional and age-related differences in atopic dermatitis clinical characteristics. J Am Acad Dermatol 2019;80(2):390-01, doi: 10.1016/j.jaad.2018.09.035.

6. Schmitz R, Atzpodien K, Schlaud M. Prevalence and risk factors of atopic diseases in German children and adolescents. Pediatr Allergy Immunol 2012;23(8):716-23, doi: 10.1111/j.1399-3038.2012.01342.

7. Flohr C, Mann J. New insights into the epidemiology of childhood atopic dermatitis. Allergy 2014;69(1):3-16, doi: 10.1111/all.12270.

8. Cork MJ, Danby SG, Vasilopoulos Y, et al. Epidermal Barrier Dysfunction in Atopic Dermatitis. J Invest Dermatol 2009;129(8):1892-08, doi: 10.1038/jid.2009.133.

9. Werfel T, Schwerk N, Hansen G, Kapp A. The diagnosis and graded therapy of atopic dermatitis. Dtsch Arztebl Int 2014;111(29-30):509-20, doi: 10.3238/arztebl. 2014.0509.

10. Eichenfield LF, Tom WL, Chamlin SL, et al. Guidelines of care for the management of atopic dermatitis Section 1.Diagnosis and assessment of atopic dermatitis. J Am Acad Dermatol 2014;70(2):338-51, doi: 10.1016/j. jaad.2013.10.010.

11. Riethmueller C. Assessing the skin barrier via corneocyte morphometry. Exp Dermatol 2018; 27(8):923930. doi: 10.1111/exd.13741.

12. Franz J, Beutel M. Gevers K, et al. Nanoscale alterations of corneocytes indicate skin disease. Skin Res Technol 2016; 22(2):174-80, doi: 10.1111/srt.12247.
13. Dufrene $Y F$, Ando T, Garcia R, et al. Imaging modes of atomic force microscopy for application in molecular and cell biology. Nat Nanotechnol 2017;12(4):295-07, doi: 10.1038/nnano.2017.45.

14. Muller DJ. AFM: a nanotool in membrane biology Biochemistry 2008; 47(31):7986-98, doi: 10.1021/ bi800753x.

15. Kashibuchi N, Hirai Y, O'Goshi K, Tagami H. Threedimensional analyses of individual corneocytes with atomic force microscope: morphological changes related to age, location and to the pathologic skin conditions. Skin Res. Technol 2002; 8(4):203-11, doi:10.1034/j.16000846.2002.00348.x

16. Enzo E, Giuseppe S. Dermoscopy in General Dermatology: A Practical Overview. Dermatol Ther (Heidelb) 2016; 6(4): 471-507, doi: 10.1007/s13555-016-0141-6

17. Iris Z, Giuseppe A, Alessandro Di S, Gerardo F, Ashfaq AM, Rainer H-W, H PS, Ralph B, Helmut K. Dermoscopy in General Dermatology. Dermatology 2006; 212(1):718,doi: 10.1159/000089015.

18. Lallas A, Kyrgidis A, Tzellos TG, Apalla Z, Karakyriou E, Karatolias A, Lefaki I, Sotiriou E, loannides D, Argenziano G, Zalaudek I. Accuracy of Dermoscopic Criteria for the Diagnosis of Psoriasis, Dermatitis, Lichen Planus and Pityriasis Rosea. Br J Dermatol 2012; 166(6):1198-205. doi: 10.1111/j.1365-2133.2012.10868.x.

19. Enzo E. Dermoscopy of Inflammatory Dermatoses (Inflammoscopy): An Up-to-Date Overview. Dermatol Pract Concept 2019; 9(3):169-180.doi: 10.5826/dpc.0903a01. eCollection 2019 Jul.

20. Elena CH, Miryam K, Natalia J-L, Lidia R, Iris Z, Josep M, Rainer H-W, Ralph PB, Ashfaq AM. Dermoscopy for the Pediatric Dermatologist Part I: Dermoscopy of Pediatric Infectious and Inflammatory Skin Lesions and Hair Disorders. Pediatr Dermatol 2013;30(2):163-71. doi: 10.1111/pde.12097. 